\title{
Composition and Seasonal Variation of the Ichthyofauna from Upper Rio Paraguaçu (Chapada Diamantina, Bahia, Brazil)
}

\author{
Alexandre Clistenes de Alcântara Santos ${ }^{1 *}$ and Érica Pellegrini Caramaschi ${ }^{2}$ \\ ${ }^{1}$ Laboratório de Ictiologia; Departamento de Ciências Biológicas; Universidade Estadual de Feira de Santana; Km \\ 03 - BR 116; Campus Universitário; clister@ig.com.br; 44031-460; Feira de Santana - BA - Brasil. ${ }^{2}$ Laboratório \\ de Ecologia de Peixes; Departamento de Ecologia; Universidade Federal do Rio de Janeiro; IB; C.P. 68020; Ilha \\ do Fundão; erica@biologia.ufrj.br; 21941-590; Rio de Janeiro - RJ - Brasil
}

\begin{abstract}
The aim of this work was to characterize the composition of the ichthyofauna of the upper course of the Rio Paraguaçu. Two excursions were carried out, one in the dry season, and the other in the rainy season, with 36 localities sampled. A total of 63 species were collected. Multivariate analyses indicated that abiotic variables such as the channel order and altitude were the main influences on the number of species present. The number of species in each excursion was equivalent in the two seasons, suggesting that seasonal changes have little influence on the ichthyofauna of this area.
\end{abstract}

Key words: Rio Paraguaçu, Chapada Diamantina, fish community, abiotic parameters, seasonality

\section{INTRODUCTION}

The Chapada Diamantina forms a watershed between the São Francisco basin and the rivers of the East basin that discharge directly in the Atlantic Ocean. The Rio Paraguaçu has its origin in the Chapada covering about $500 \mathrm{~km}$ up to its estuary in the west portion of the Todos os Santos Bay. This river is one of the largest basins of northeastern Brazil, but remains almost unexplored ichthyologically (Higuchi et al. 1990). The headwaters of the Rio Paraguaçu host a rich and endemic ichthyofauna (Pinna, 1992).

The anthropic interference in the rivers of the Chapada Diamantina is represented, mainly by former diamond mining; presence of towns and cities; farming with intense activity of irrigation; and adventure tourism in increasing expansion. These activities make it necessary to implement urgent strategies of preservation of the Chapada. However, the real condition of the aquatic biota is yet unknown. The objective of this work was to characterize the composition of the ichthyofauna of the upper Rio Paraguaçu drainage.

\section{MATERIALS AND METHODS}

\section{Field sampling}

Two excursions were carried, one in rainy period (March 1999) and one in the dry period (November 1999), totalizing 36 localities of sampling in the high course of the River Paraguaçu and its main tributaries (Fig. 01).

\footnotetext{
* Autor correspondente
} 
Sampling equipment was used according to the microhabitat conditions: gillnets, handnets, cast seines, fish trap and bolter. Order of the canal, altitude, width, depth, stream velocity, outflow, temperature and transparency of the water were registered.

Specimens were fixed in $4 \%$ formaldehyde and later were preserved in ethanol $\left(70^{\circ} \mathrm{GL}\right)$. Species were identified by literature (Menezes, 1969; Gosse, 1976; Gery, 1977; Garavello, 1979; Britski et al., 1986; Burgess 1989; Vari 1991; Pinna 1992; Buckup 1993; Malabarba 1998) and by comparison with the collections at Museu Nacional do Rio de Janeiro and Museu de Zoologia da Universidade de São Paulo. Specialists on some of the groups were also consulted. In order to build the taxonomic list, in this study was adopted the classification of Reis et al. (2003).

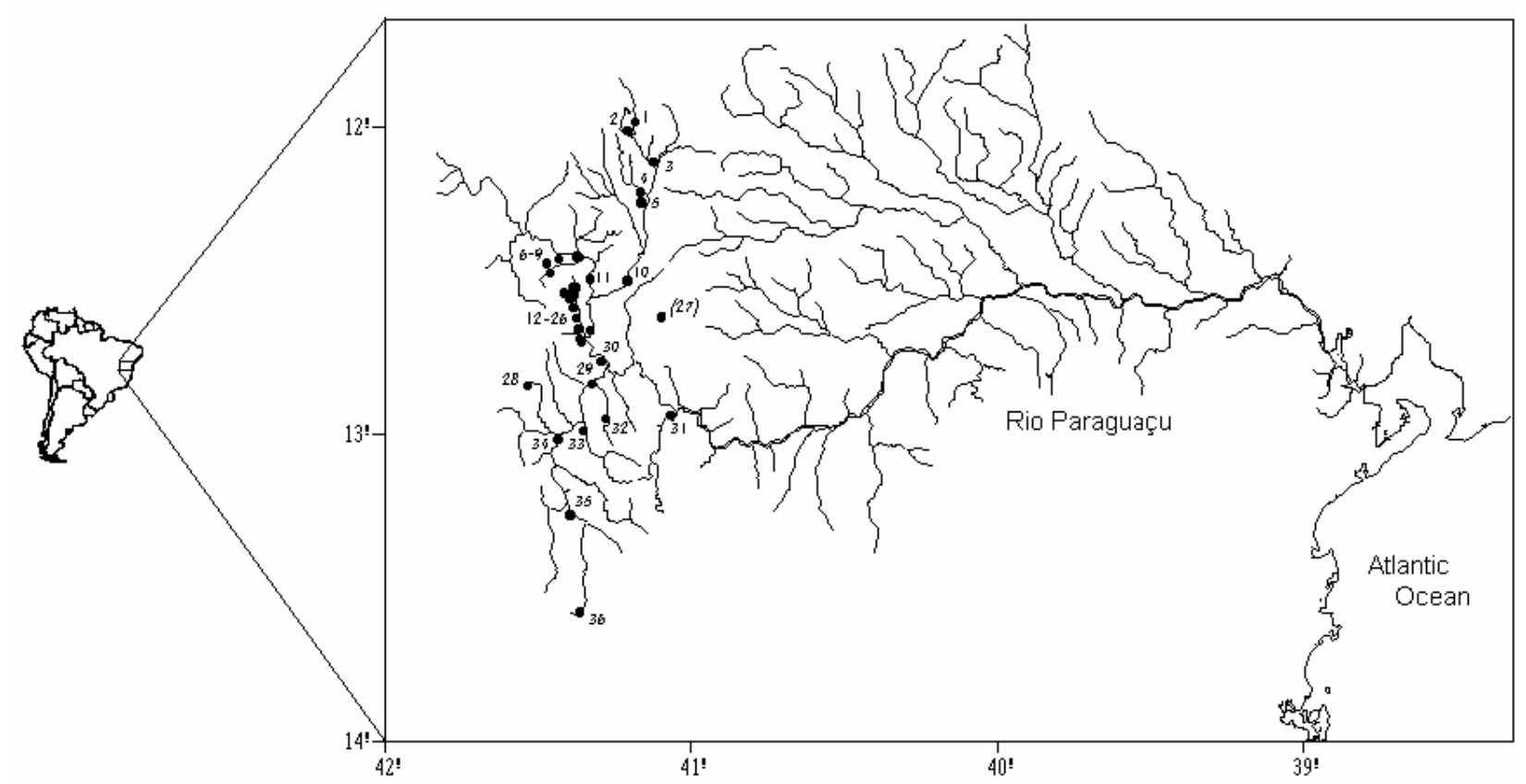

Figure 1 - Study area with indication of the 36 sampling sites. The codes for the localities in Table 01.

\section{Data Analysis}

The number of species per locality in each period of sampling was compared. $\mathrm{T}$ test was used to determine statistical differences in the number of species between the two periods of sampling. Multivariate Principal Components Analysis (PCA) and Cluster Analysis were used to group the localities in accordance with environmental variables and the number of species, respectively. Logarithmic transformations of both environmental variables and species number data were performed. Cluster analysis was performed using Ward's method of linkage for the production of the dendrogram. For these analysis, only localities sampled in both periods were used.

\section{RESULTS}

\section{Fish Assemblage}

Fishes from 63 species representing 42 genera and 16 families were collected, representing five orders: Characiformes (37 species, 58.7\%); Siluriformes (16 species, $25.4 \%)$; Cyprinodontiformes (04 species, 6.4\%); Perciformes (05 species, 7.9\%); e Gymnotiformes (01 specie, 1.6\%). The most representative family was Characidae with 25 species. Loricariidae and Trichomycteridae with 5 species, Cichlidae and Poeciliidae with 4 species, Crenuchidae, Erythrinidae and Heptapteridae with 3 species were also well represented families (Table 1). Ten out of 63 species found (16\%) were possibly new, not mentioning the species of Astyanax. 


\section{Spatial and temporal variation}

No significant differences were shown in the species number by locality among two periods $(\mathrm{p}=0.90)$. The species number varied from one up to 15 species (Table 2). The river order of the canal varied from one up to 6 (sensu Strahler, 1957); the altitude varied from $285 \mathrm{~m}$ up to $1117 \mathrm{~m}$; the outflow from $0.12 \mathrm{~m}^{3} / \mathrm{s}$ up to $6.89 \mathrm{~m}^{3} / \mathrm{s}$; the width from $1.2 \mathrm{~m}$, up to $33.9 \mathrm{~m}$ and the depth from $0.1 \mathrm{~m}$ up to $5.6 \mathrm{~m}$.

Cluster analysis considering the presence/absence fish data presented four groups in both excursions. In the first excursion, group 1 represented localities with more species (12-15), being composed mainly by localities in the tributaries of Rio Paraguaçu, such as the Utinga, Una and Santo Antônio rivers. Group 2 represented localities with intermediate number of species (5-8), being composed basically by minor tributaries of São José and Santo Antônio rivers. Group 3 presented low number of species (1-3) being composed by little streams of low order. Finally, group 4 represented localities in São José and Paraguaçu rivers next its headwaters, also with low number of species (Fig. 2). The codes for the localities are shown in Table 2.

In the second excursion, group 1 also represented localities with more species (9-15) being composed mainly by localities of the Utinga, and Santo Antônio rivers. Group 2 represented localities with low number of species (1-5), being composed basically by minor streams, Paraguaçu next to its headwaters and others rivers of low order. Group 3 presented high number of species (10-12), being composed by tributaries of São José. Group 4, in the second excursion represented by localities in São José and some of its tributaries, Rio Una, a tributary of the Santo Antônio and one locality of the Rio Paraguaçu in Andarai (Fig. 2). The codes for the localities are shown in Table 2.

The PCA obtained by the analysis of the environmental variables in the first excursion explained $48.3 \%$ of the total variance. Component 1 explained $29.1 \%$ of the total variance and presented positive weight for altitude and negative for richness, order and outflow. Component II explained $19.3 \%$ of the total variance and presented positive weight for temperature and richness and negative for depth and altitude. The resulting diagram from Components I and II (Fig. 03) separated the localities along the component I, with localities of more altitude on the right side and others with more richness, width and order on the left side. Component II, in turn, separated the localities with higher temperature above and localities with more depth and outflow below. The codes for the localities are shown in Table 2.

In the second excursion PCA explained $61.7 \%$ of the total variance. Component I explained $45.2 \%$ of the total variance and presented positive weight for order, temperature, depth and richness. Component II explained $16.5 \%$ of the total variance and presented positive weight for outflow and width. The resulting diagram from Components I and II (Figure 03) separated the localities along the component I, with localities of greater altitude on the left side and others with greater richness, width and order on the right side. Component II, in turn, separated the localities with higher temperature below and localities with more depth and outflow above. The codes for the localities are shown in Table 2.

Table 01 - List of order, families, subfamilies and species of fish caught in upper Rio Paraguaçu.

\begin{tabular}{|c|c|c|c|}
\hline Order & Family & Subfamily & Species \\
\hline \multirow[t]{9}{*}{ Characiformes } & Parodontidae & & Apareiodon hasemani Eigenmann, 1916 \\
\hline & Curimatidae & & Steindachnerina elegans (Steindachner, 1875) \\
\hline & & & Cyphocharax gilberti (Quoy and Gaimard, 1824) \\
\hline & Prochilodontidae & & Prochilodus affinis Reinhardt, 1874 \\
\hline & Anostomidae & & Leporinus sp. \\
\hline & Crenuchidae & Characidiinae & Characidium cf. bahiensis \\
\hline & & & Characidium cf. bimaculatum \\
\hline & & & Characidium sp. nov. \\
\hline & Characidae & Incertae sedis & Astyanax bimaculatus lacustris (Reinhardt, 1874) \\
\hline
\end{tabular}




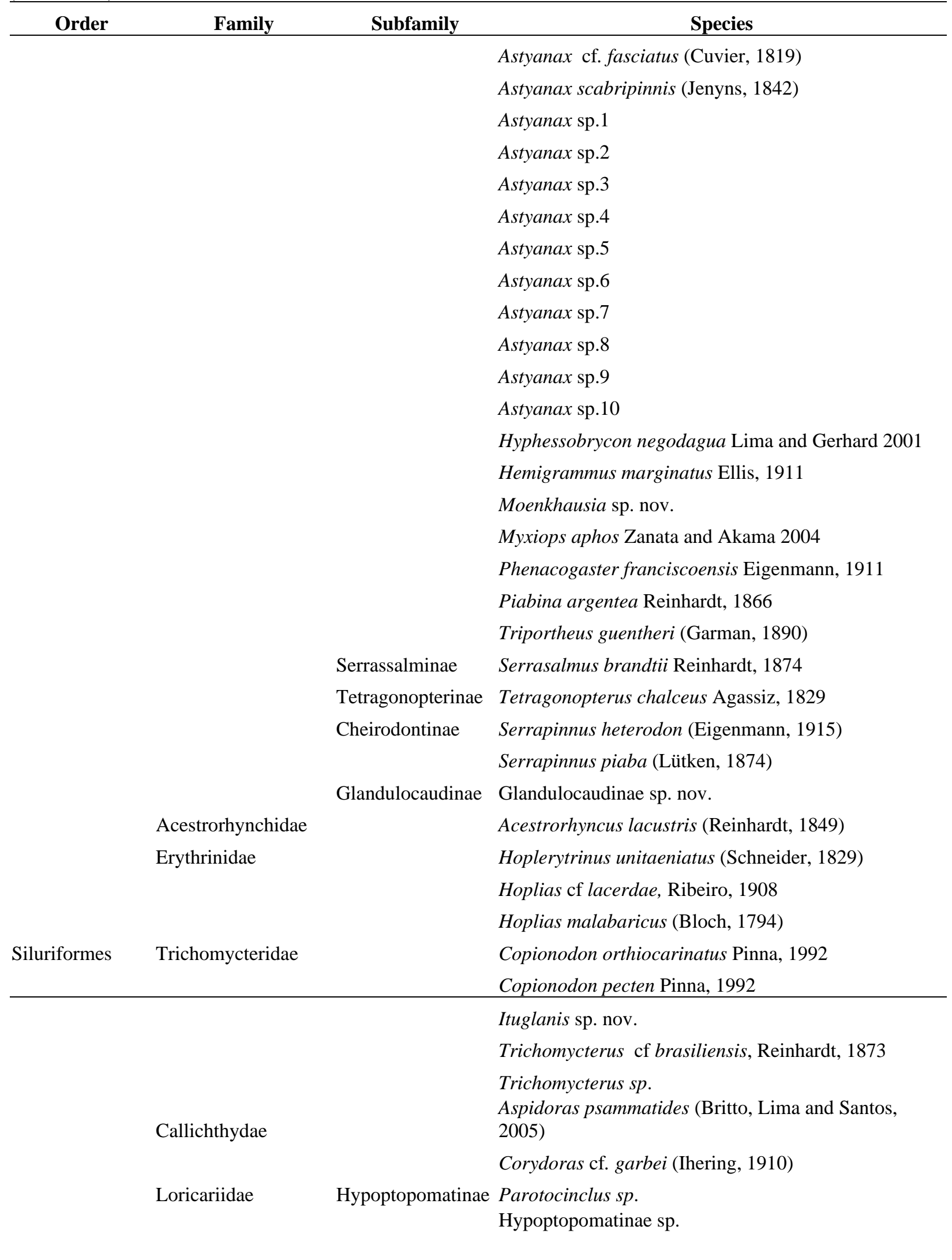




\begin{tabular}{|c|c|c|c|}
\hline Order & Family & Subfamily & Species \\
\hline & \multirow{6}{*}{ Heptapteridae } & Hypostominae & Hemipsilichthys sp. nov. \\
\hline & & & Hypostomus sp. \\
\hline & & & Pterygoplichthys sp. \\
\hline & & & Pimelodella cf. laurenti (Fowler, 1941) \\
\hline & & & Rhamdia quelen (Quoy and Gaimard, 1824) \\
\hline & & & Rhamdiopsis sp. nov. \\
\hline & Auchenipteridae & & Parauchenipterus galeatus Linnaeus, 1766 \\
\hline Gymnotiformes & Gymnotidae & & Gymnotus carapo Linnaeus, 1758 \\
\hline \multirow[t]{4}{*}{ Cyprinodontiformes } & Poeciliidae & & Pamphorichthys hollandi (Henn, 1916) \\
\hline & & & Pamphorichthys sp. nov. \\
\hline & & & Poecilia reticulata Peters, 1860 \\
\hline & & & Poecilia vivipara (Scheneider,1801) \\
\hline \multirow[t]{5}{*}{ Perciformes } & Cichlidae & & Astronotus ocellatus (Cuvier, 1829) \\
\hline & & & Cichlasoma facetum (Jenyns, 1842) \\
\hline & & & Cichla cf. temensis Humboldt, 1833 \\
\hline & & & Geophagus brasiliensis (Quoy and Gaimard, 1824) \\
\hline & & & Geophagus sp. nov. \\
\hline
\end{tabular}

Table 02- Number of species by localities.

\begin{tabular}{lllcc}
\hline \multirow{2}{*}{ Site number } & Locality & Código & Rainy & dry \\
\hline 1 & Rio do Riachão & RIAC & 4 & 5 \\
3 & Rio Utinga (1) & UTI1 & 15 & 13 \\
4 & Rio Cachoeirinha & CACH & 14 & 9 \\
5 & Rio Utinga (2) & UTI2 & 14 & 9 \\
6 & Afluente do Santo Antônio & COSA & 2 & 5 \\
7 & Rio Toalhas & FOTO & 7 & 7 \\
8 & Rio Santo Antônio (Palmeiras) & SAPA & 12 & 15 \\
9 & Rio Mosquito & RIMI & 8 & 6 \\
11 & Rio Santo Antônio (Camelo) & SACA & 12 & 10 \\
12 & Rio Mandassai & RIMA & 2 & 3 \\
13 & Poço Mandassai & POMA & 3 & 8 \\
15 & Rio São José (Nascente) & SJL2 & 6 & 7 \\
16 & Rio Mucugezinho & RIMU & 2 & 2 \\
17 & Córrego do Lapão & COLA & 2 & 1 \\
18 & Rio Lapão & RILA & 3 & 6 \\
19 & Rio Lençóis & RILE & 7 & 4 \\
21 & Rio Ribeirão & RIRI & 6 & 5 \\
\hline
\end{tabular}


(Cont. Table 1)

\begin{tabular}{lllcc}
\hline \multirow{2}{*}{ Site number } & Locality & Código & Rainy & dry \\
\hline 22 & Rio Capivara & CAPI & 13 & 13 \\
23 & Rio São José (Lençóis) & SJL1 & 8 & 6 \\
24 & Rio Caldeirão & RICA & 8 & 10 \\
25 & Córrego Roncador/Caldeirão & CORC & 3 & 4 \\
26 & Rio Roncador & RIRO & 7 & 12 \\
27 & Rio Santo Antônio (Remanso) & SARE & 5 & 3 \\
28 & Rio Santo Antônio (Andarai) & SAAN & 13 & 12 \\
30 & Rio Paraguaçu (Andarai) & PAR1 & 2 & 5 \\
31 & Rio Una & RUNA & 12 & 8 \\
32 & Rio Piabas & PIAB & 3 & 3 \\
33 & Rio Cumbuca. & RICU & 1 & 0 \\
35 & Rio Paraguaçu (Cascavel) & PAR3 & 5 & 5 \\
36 & Rio Paraguaçu (Barra da Estiva) & PAR2 & 6 & 5 \\
\hline & Mean & & 6.8 & 6.7 \\
& Standard Deviation & & 4.4 & 3.8 \\
\hline
\end{tabular}

* Only localities samples in both periods are listed.

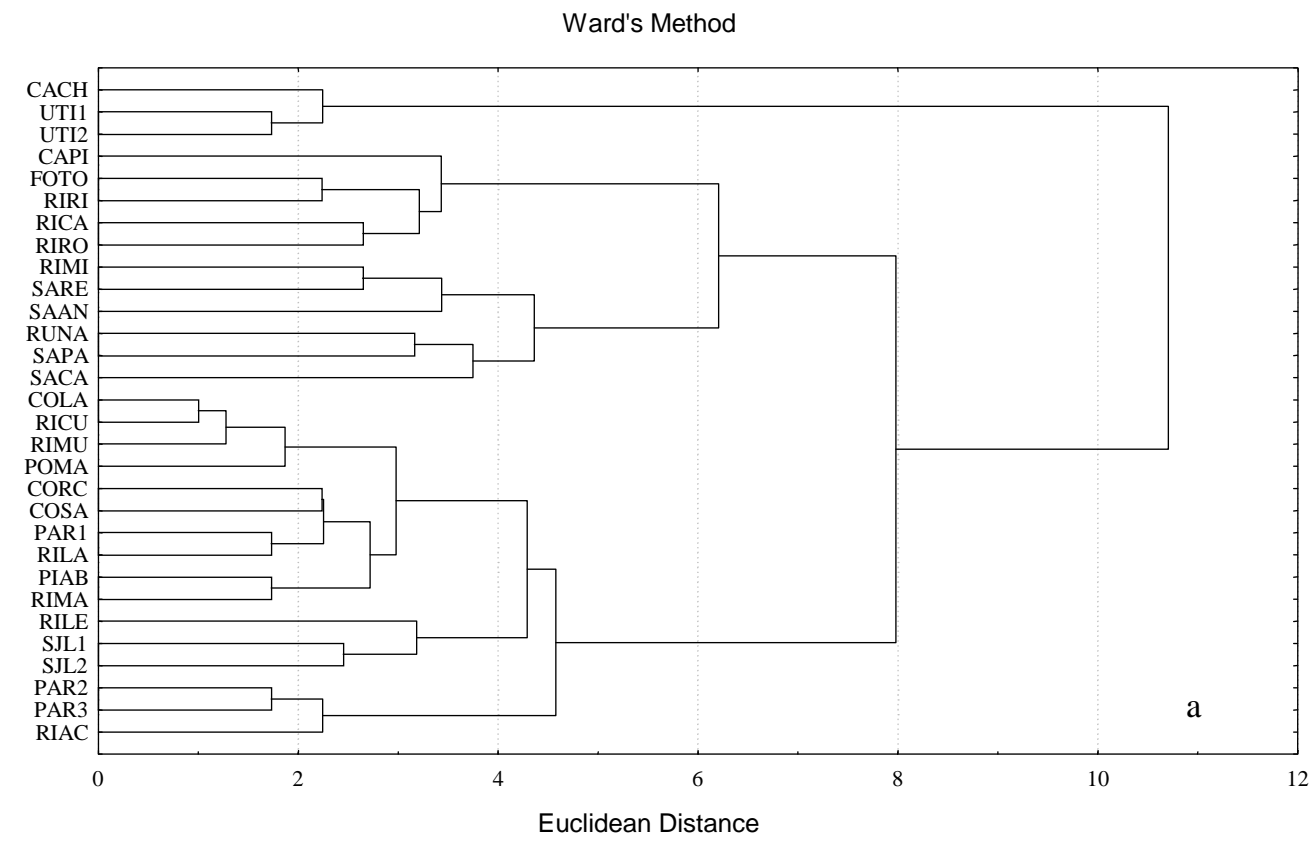




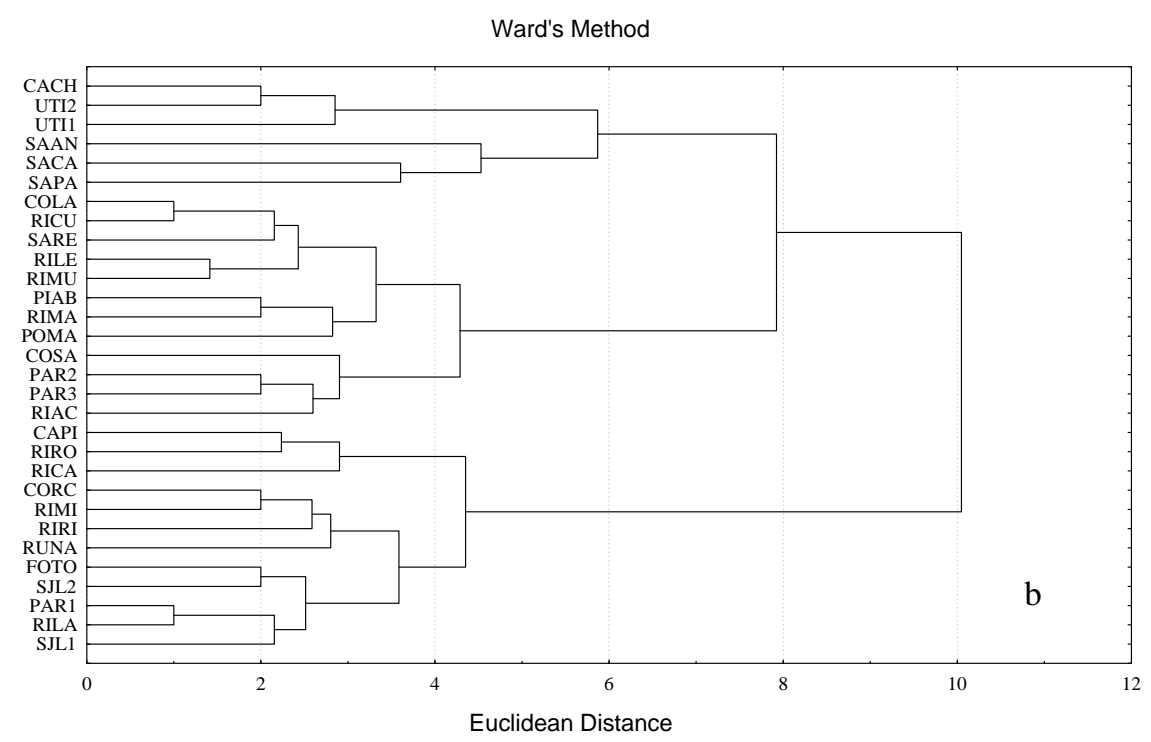

Figure 02 - Cluster analysis of the data of presence or absence in the first (a) and second (b) excursion, coded by 30 sampling sites in both excursions. The codes for the sampling sites in Table 2.

\section{DISCUSSION}

The discovery of 10 species which were new in the Chapada Diamantina ratifie the little knowledge on ichthyofauna of the northeast region. One of these new species, Myxiophs aphos recently described, represented a new characid genus and species. Another important fact was the presence of species of subfamily Copionodontinae, endemic and recently described for the Chapada Diamantina (Pinna, 1992). The number of species per locality was equivalent in the dry and rainy periods, suggesting little seasonal influence in the composition of fish assemblages in this area. The multivariate analyses indicated constant abiotic parameters as the order of the canal and the altitude, as main influences in the characterization of the localities and consequently in the number of species of each one of them. Changes in parameters such as the temperature and the outflow, were determinant in the organization of the community of fish. In accordance with LoweMcconnel (1999), in rivers of tropical regions the seasonality is induced mainly for changes in the water level. In larger rivers of greater order, which are subjected to floods an increase in the number of species associated with migratory species is expected. Melo (2000) considers the size of the basin as a determinant factor in the variation of the number of species between dry and rain seasons, as observed in streams in central Brazil.

In larger basins, the migration processes are more frequent, determining lesser similarity between dry and rainy season, and this difference in the environment tends to increase the substitution of species of one habitat for the other, increasing, therefore, the beta diversity (Magurran, 1998; Ricklefs and Schluter, 1993). In this study, the majority of the localities present order channel between 1 and 3 and reduced width, consequently less influenced by migratory processes.

The PCA revealed the importance of factors as the order of the channel and the altitude in the ichthyofaunistic composition of the region. Several authors (Martin-Smith, 1998; Oberdorff et al. 1998; Marsh-Mattheus and Matthews, 2000) have used this analysis to determine the existence of a physical gradient responsible for the organization of the fish communities. Because of their complementary nature, PCA and cluster analyses together provide a powerful tool when identifying patterns in the structure of community data (Gauch, 1982). Caramaschi (1986) emphasized the importance of characteristics related to the river size (order of the channel, width and depth) in the distribution of stream 
ichthyofauna. Marsh-Matthews and Matthews (2000) affirmed that the relation between stream velocity and depth can be reflected in the increase of the species richness as consequence of an increase in the habitat complexity.

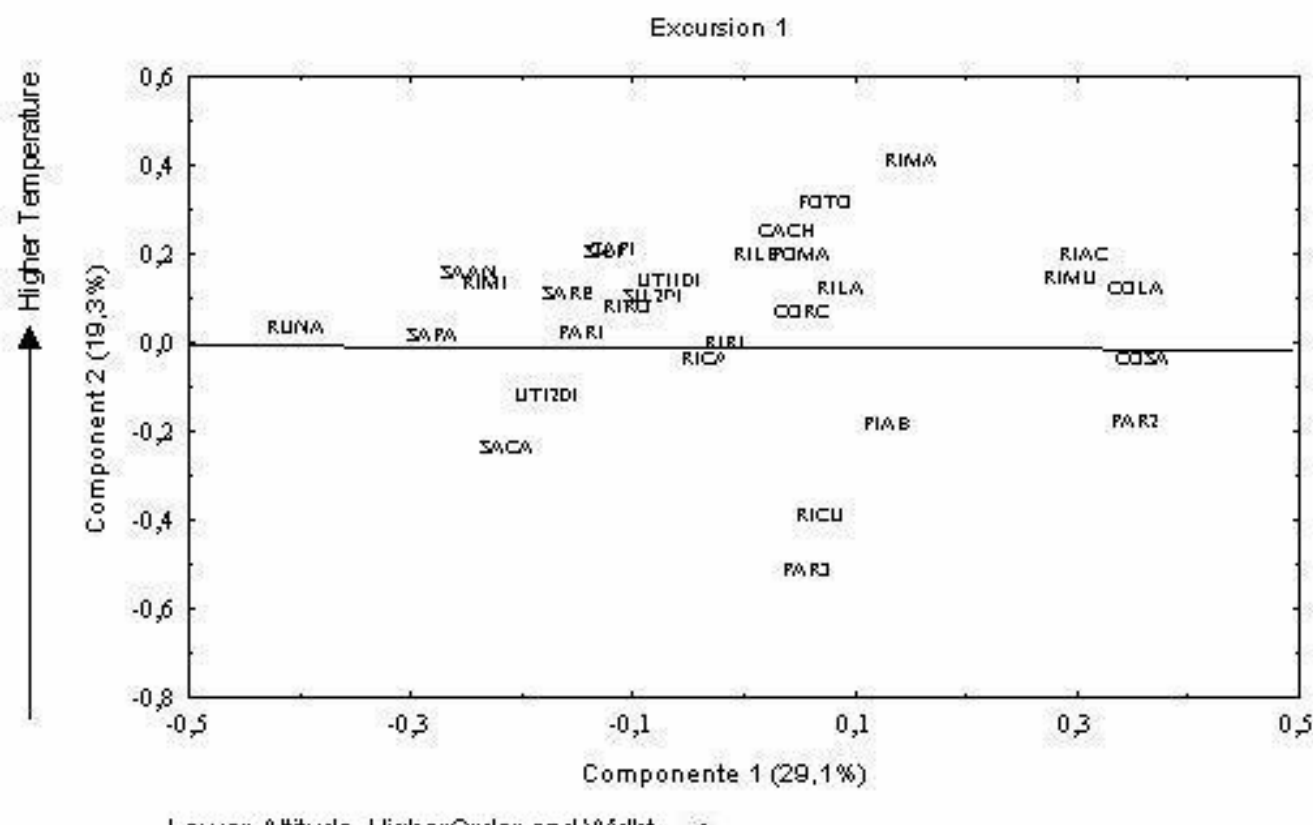

Lower Altitude, Higherorder and Widht

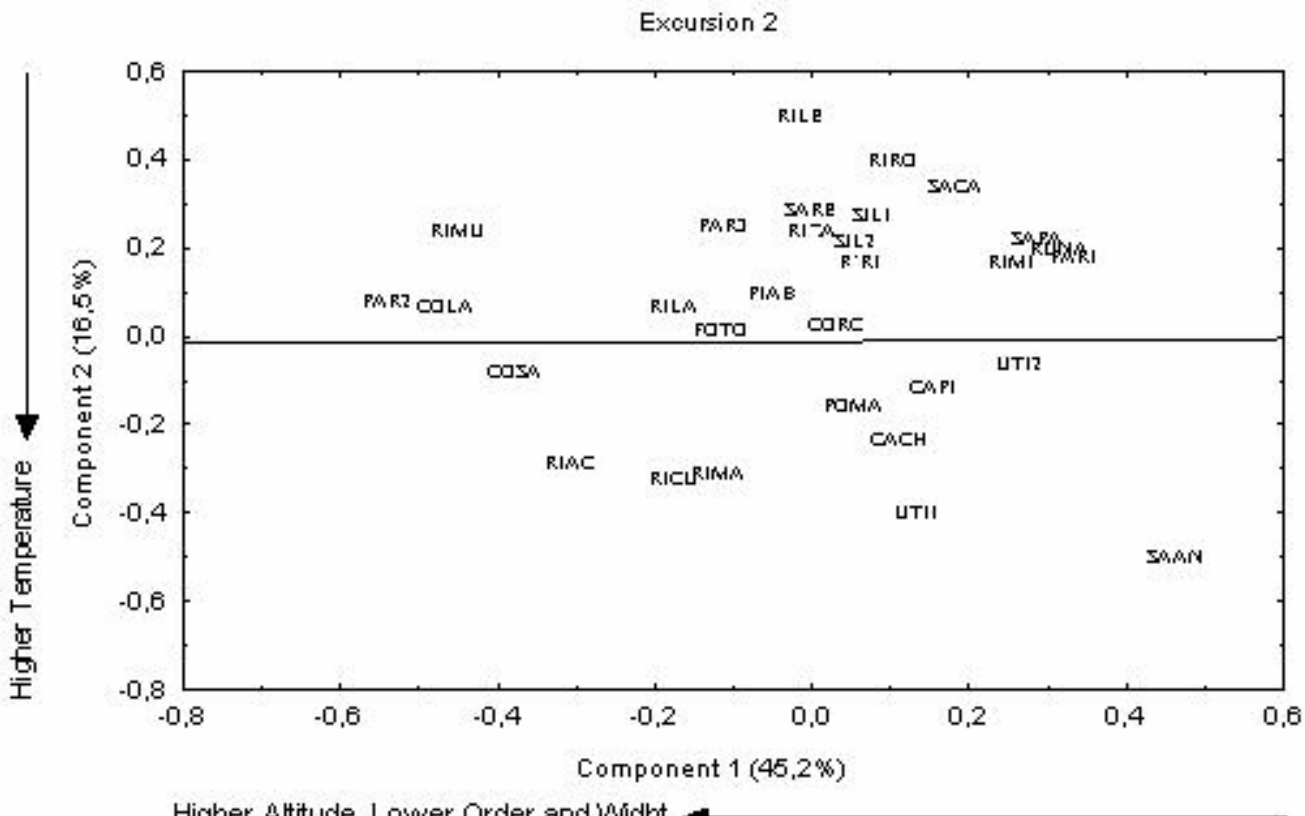

Figure 03 - Ordination diagram for the two first principal components in the first and second excursion, coded by 30 sampling sites in both excursions. The codes for the sampling sites in Table 2 .

Despite the large number of studies carried out through the last years on the ichthyofauna of South
America, this was still poorly known, in particular in the Northeast region. Recently, Higuchi et al. 
(1990); Pinna (1992); Lima and Gerhard (2001), Lima et al. (2001) and Zanata and Akama (2004), Britto et al. (2005), described new genera and species of Douradidae and Characidae, and a new subfamily of Trichomycteridae in the Paraguaçu basin. In this work, 10 new species were determined (including the recently described Hyphessobrycon negodagua, Aspidoras psammatides and Myxiops aphos). This fact showed the poor knowledge on the local ichthyofauna and the high rate of endemism, probably due to the natural characteristics of the region. Castro (1999) mentioned that smaller species made up to at least $50 \%$ of the total of species in river environments of small and average sizes and that they presented a high level of endemism. Those, however, have been poorly studied so far. The ichthyofauna of the upper Rio Paraguaçu registered in this work was composed mainly by small size fishes. Small fishes normally present minor moving capacity and are more susceptible to vicariance events, in contraposition to biggest species that generally present great geographic variation and little morphologic variation (Castro, op. cit.).

The absence of previous studies on the ichthyofauna of the Chapada did not allow to compare the current situation with that existed before the antropic interference. It could be expected that present result would represent a step to future and more complete ichthyofaunistic inventories, and for the delimitation of critical areas to the ichthyofauna.

\section{ACKNOWLEDGEMENTS}

We thank to Capes/PICDT for granting the scholarship during the accomplishment of part of this study. We also thank to Dr. Gustavo Nunan at Museu Nacional/UFRJ for allowing to use of the Setor de Ictiologia (Division of Ichthyology) during this work. To Projeto Nordeste de Pesquisa/CNPq and to UEFS for the support on the samplings procedures. To Marconi P. Sena, Edjane Santos, Manina Kowalsk and Benedito Marques (UEFS) for their help in samplings as well as in the triage of the material.

\section{RESUMO}

$\mathrm{O}$ rio Paraguaçu origina-se nas encostas úmidas da Chapada Diamantina e atravessa grande parte do estado da Bahia até desembocar na baía de Todos os Santos. Neste trabalho foi caracterizada a composição da ictiofauna do alto curso do rio Paraguaçu na região da Chapada Diamantina. Para isso, foram realizadas duas excursões de coleta, nas estações seca e chuvosa, onde 36 localidades foram amostradas. Um total de 63 espécies foi coletado e as análises multivariadas indicaram a maior influência de fatores como a ordem do canal e a altitude em relação ao número de espécies registradas. O número de espécies em cada excursão foi equivalente nas estações seca e chuvosa sugerindo pouca influência da sazonalidade na ictiofauna do alto curso do Rio Paraguaçu.

\section{REFERENCES}

Britski, H. A.; Sato, Y. and Rosa, A. B. S. (1986), Manual de identificação de peixes da região de Três Marias (com chaves de identificação para os peixes da bacia do São Francisco). 2.ed. CODEVASF, Brasília.

Britto, M. R., Lima, F. C. T. and Santos, A. C. A. 2005. A new Aspidoras (Siluriformes: Callichthyidae) from rio Paraguaçu basin, Chapada Diamantina, Bahia, Brazil. Neotropical Ichthyology, 3(4): 473-479.

Buckup, P. A. (1993), Review of the characidiin fishes (Teleostei: Characiformes), with descripitions of four new genera and ten new species. Ichthyol. Explor. Freshwaters, 4, 97-154.

Burgess, W. E. (1989), An atlas of freshwater and marine catfishes: a preliminary survey of the Siluriformes. Tropical Fish Hobbyist Publications, Inc., Neptune City, NJ.

Caramaschi, E. P. (1986), Distribuição da ictiofauna de riachos das bacias do Tietê e do Paranapanema, junto ao divisor de águas (Botucatu - SP). Tese de doutorado, Universidade Federal de São Carlos, São Paulo, Brasil.

Castro, R. M. C. (1999), Evolução da ictiofauna de riachos americanos: Padrões gerais e possíveis processos causais. In: Caramaschi, E. P., Mazzoni, R. and Peres-Neto, P.R. (eds.). In-Ecologia de peixes de riachos. Série Oecologia Brasiliensis, vol.VI. Computer and Publish Editoração, Rio de Janeiro, pp. 91-138. 
Pinna, M. C. C. (1992), A new subfamily of Trichomycteridae (Teleostei, Siluriformes), lower loricarioid relationships and a discussion on the impact of additional taxa for phylogenetic analysis. Zoological Journal of the Linnean Society, 106, 175229.

Gauch, H. G. (1982), Multivariate analysis in community ecology. Cambridge University Press, Cambridge, England.

Garavello, J. C. (1979), Revisão taxonômica do gênero Leporinus Spix, 1829 (Ostariophysi, Anostomidae). Tese de Doutorado, Instituto de Biociências da USP, São Paulo.

Gery, J. (1977), Carachoids of the word. T.F.H. Publications, Neptune.

Gosse, J. P. (1976), Révision du genre Geophagus (Pisces: Cichlidae). Académie royale des Sciences d'Outre-Mer. Classe des Sciences Naturelles et Médicales, 19(3), 1-212.

Higuchi, H., Britski, H. A. and Garavello. J. C. (1990), Kalyptodoras bahiensis, a new genus and species of thorny catfish from norteastern Brazil (Siluriformes: Doradidae). Ichthyol. Explor. Freshwaters, 1(3), 219225.

Lima, F. C. T. and Gerhard, P. (2001), A new Hyphessobrycon (Characiformes: Characidae) from Chapada Diamantina, Bahia, Brazil, with notes on its natural history. Ichthyol. Explor. Freshwaters, 12(2), 105-114.

Lima, F. C. T., Di Dario, F. and Gerhard, P. (2001), Um novo Tetragonopterinae (Ostariophysi: Characiformes: Characidae) do alto rio Paraguaçu, Bahia. Trabalho apresentado no XIV Encontro Brasileiro de Ictiologia, 7-11 de Janeiro, São Leopoldo, RS.

Lowe-McConnel, R. H. (1964), The fishes of the Rupununi savanna district of Britsh Guiana, South America. Part I - Ecological groupings of fish species and effects of the seasonal cycle on the fish species and effects of the seasonal cycle on the fish. J. Linn. Soc. Zool., 45(304), 103-144.

Magurran, A. E. (1988), Ecological diversity and its measurement. Princeton University Press, Princeton, New Jersey, USA.
Malabarba, L. R. (1998), Monophyly of the Cheirodontinae, Characters and Major Clades (Ostariophysi: Characidae). In-Phylogeny and classification of neotropical fishes. EDIPUCRS, Porto Alegre. pp. 193-233.

Marsh-Matthews, E. and Matthews, W. J. (2000), Geographic, terrestrial, and aquatic factors: Which most influence structure of midwestern USA stream fish assemblages? Ecology of Freshwater Fish, 9, 1321.

Martin-Smith, K. M. (1998), Relationships between fishes and habitat in rainforest streams in Sabah, Malaysia. Journal of Fish Biology, 52, 458-482.

Melo, C. E. (2000), Ecologia comparada da ictiofauna em córregos de cerrado do Brasil central: Bases para a conservação das espécies. Tese de Doutorado, Universidade Federal de São Carlos, São Paulo.

Menezes, N. A. (1969), Systematics and evolution of the tribe Acestrorhynchini (Pisces, Characidae). Arquivos de Zoologia, Museu de Zoologia do Estado de São Paulo. 18(1-2), 1-150.

Oberdoff, T.; Hugueny, B.; Conpin, A. and Belkessam, D. (1998), Non-interactive fish communities in the coastal streams of North-western France. Journal of animal Ecology, 67, 472-484.

Reis, R. E., Kullander, S. O. and Ferraris-Jr., C. J. (2003), Checklist of the Freshwater Fishes of South and Central America. EDIPUCRS, Porto Alegre.

Ricklefs, R. E. and Schulter, D. (1993), Species diversity in ecological communities. Historical and geographical perspectives. The University of Chicago Press, Ltda., London.

Strahler, A. N. (1957), Quantitative analysis of watershed geomorphology. American Geophysical Union Transactions, 38, 913-920.

Vari, R. P. and Weitzman, S. H., 1990. A review of the phylogenetic biogeography of the freshwater fishes of South America. In-Vertebrates in the Tropics. Museu Alexander Koenig, Bonn. p. 381-393.

Zanata, A. M. and Akama, A. 2004. Myxiops aphos, new characid genus and species (Characiformes: Characidae) from the rio Lençóis, Bahia, Brazil. Neotropical Ichthyology, 2(2), 45-54. 